\title{
Major Dietary Patterns in Relation to Chronic Low Back Pain; a Cross- sectional Study from RaNCD Cohort
}

\author{
Yahya Pasdar \\ Kermanshah University of Medical Sciences \\ Behrooz Hamzeh \\ Kermanshah University of Medical Sciences \\ Sheno Karimi \\ Kermanshah University of Medical Sciences \\ Shima Moradi ( $\square$ shima.moradi@kums.ac.ir) \\ Kermanshah University of Medical Sciences https://orcid.org/0000-0002-6507-7928 \\ Sahar Cheshmeh \\ Kermanshah University of Medical Sciences \\ Mohammad Bagher Shamsi \\ Kermanshah University of Medical Sciences \\ Farid Najafi \\ Kermanshah University of Medical Sciences
}

\section{Research}

Keywords: low back pain, diet, dietary pattern, high protein diet

Posted Date: September 16th, 2021

DOI: https://doi.org/10.21203/rs.3.rs-885613/v1

License: (c) (i) This work is licensed under a Creative Commons Attribution 4.0 International License. Read Full License 


\section{Abstract \\ Background}

Chronic low back pain (LBP) is the most common musculoskeletal pain that affects a person's daily activities. This present study aimed at evaluating the relationship between major dietary pattern and Chronic LBP.

\section{Methods}

This cross- sectional study was applied using data from Ravansar non- communicable diseases (RaNCD) cohort study. Chronic LBP was diagnosed by the RaNCD cohort study physician. Dietary patterns were evaluated by principal component analysis. The three identified dietary patterns included: 1) vegetarian dietary pattern which included vegetables, whole grain, legumes, nuts, olive, vegetable oil, fruits, and fruit juice; 2) high protein diet related to higher adherence to red and white meat, legumes, nuts, and egg; and 3) unhealthy dietary pattern characterized with higher intake of salt, sweet, dessert, hydrogenated fat, soft drink, refined grain, tea, and coffee.

\section{Results}

$22.5 \%$ of participants had chronic LBP Higher following high protein dietary pattern was associated with lower risk of chronic LBP in crude (OR: $0.79,95 \% \mathrm{Cl}: 0.69-0.9$ ) and adjusted model (for age, sex, smoking, drinking, diabetes, physical activity, and body mass index) (OR: $0.84,95 \% \mathrm{Cl}: 0.72-0.97$ ). In addition, after controlling for the mentioned potential confounders, participants in the highest category of unhealthy dietary pattern were higher at risk of chronic LBP compared with those in the lowest category (OR: $1.13,95 \% \mathrm{Cl}$ : 1.01-1.32).

\section{Conclusions}

Higher adherence to high protein diet significantly the decreased risk of chronic LBP prevalence. In addition, we found that following unhealthy dietary pattern was associated with higher risk of chronic LBP.

\section{Introduction}

Low back pain (LBP) is the fifth most common cause among the reasons for referring to doctors; many adults experience it throughout their lives [1]. LBP is caused by problems related to the intervertebral discs, nerves, muscles, etc. in the lumbar and sacral vertebrae [2]. Most LBP patients (up to $90 \%$ ) have non-specific pain without any clear cause [3]. LBP is classified into three categories based on the duration of symptoms. Acute LBP is often the result of actual or near tissue injury or sprain, which has been present for six weeks or less, and it tends to settle on its own with personal care. Sub-acute LBP has a six- to 12-week duration, and chronic LBP lasts longer than 12 weeks. According to this category, chronic LBP often persists even though the initial injury has healed. These cases are more likely to be referred for treatment than the more acute cases that linger untreated [4].

People with chronic LBP have difficulty in social and occupational activities, and even the resulting pain affects a person's mood and puts a heavy burden on the treatment system; overall, chronic LBP is the most common cause of disability in a person's daily activities [5]. It should be noted that many people may not see a doctor and consider a self-medication approach, so its prevalence is higher in communities [6]. Evidence suggests that stress, anxiety, sedentary lifestyle, hard work, obesity, and diet are involved in the etiology of chronic LBP [7].

Increased levels of pro- inflammatory mediators in the body can be involved in the pathogenesis of chronic LBP $[8,9]$. Following an unhealthy diet pattern by producing pro-inflammatory mediators upsets the balance of these mediators in the body [10]. Higher adhere to Western diet, which is characterized by higher intake of refined grains, red meat, processed meat, high saturated fat, trans-fatty acids, sweet sugary foods, and caffeine, as an unhealthy diet is associated with the production of high levels of cytokines, interleukins, Creactive protein (CRP) and tumor necrosis factor alpha (TNF-a) $[2,11]$. On the other hand, a healthy diet pattern related to adequate and balanced intake of all food groups can moderate the inflammatory conditions of the body $[12,13]$. 
According to the high prevalence of chronic LBP in the worldwide and the importance of proper diet in reducing inflammatory conditions, it seems necessary to conduct a study to determine the relationship between major dietary patterns and the risk of chronic LBP among in Kurdish adults participating in Ravansar non- communicable diseases (RaNCD) cohort study.

\section{Material And Methods}

Study design and participants

This cross-sectional study was conducted on data from recruitment phase of RaNCD cohort study. This population-based study was performed on Kurdish participants (4770 men and 5289 women) aged 35-65 years in Ravansar, Kermanshah province, Western Iran. This study was developed by the PERSIAN (Prospective Epidemiological Research Studies in Iran) mega cohort study and was approved by the Ethics Committees in the Ministry of Health and Medical Education, the Digestive Diseases Research Institute, Tehran University of Medical Sciences, Iran. The details of this study were in previous studies [14,15]. This cohort study was approved by the Ethics Committee of Kermanshah University of Medical Sciences (No: KUMS.REC.1394.318).

Inclusion criteria for this study were participants who provided complete information for RaNCD cohort study. We also did not include participants with cardiovascular diseases $(n=1118)$, thyroid $(n=738)$, and cancer $(n=93)$ diseases due to possible dietary changes. Also, pregnant women $(n=134)$ were included to this study. After excluding these participants, the participants whose calories intake were not in the range of $800-4200 \mathrm{Kcal} /$ day $(n=437)$, were not included in the study. Furthermore, 41 participants with missing data were excluded.

\section{Data sources/ measurements}

The necessary data were obtained from RaNCD cohort study including demographics, physical activity, dietary intake, anthropometric indices, and medical history of chronic LBP. Also, history of smoking and drinking was evaluated based on the history of smoking, being a passive smoker, and alcohol consumption of the participants [14].

Anthropometry

The weight of participants was measured with InBody 770 device (Inbody Co, Seoul, Korea) with the least clothing and without shoes in the study site in Ravansar. The automatic stadiometer BSM 370 (Biospace Co., Seoul, Korea) was applied to measure their height in a standing position without shoes with a precision of $0.1 \mathrm{~cm}$. Body mass index (BMI) was calculated by dividing weight in $\mathrm{kg}$ into height square in meter. Non-stretched and flexible tape was used to measure waist circumference in standing position at the level of the iliac crest three times, and the average was recorded.

Dietary pattern

Dietary intake of the studied participants was assessed using a validated semi- quantitative 130 items food frequency questionnaire developed by RaNCD cohort study. The details of this questionnaire were described in the previous studies $[14,16]$. To determine dietary patterns, 130 food items were categorized into 31 food groups based on the similarity of nutrients (Table 1). Principal component analysis was used to identify the major dietary patterns. In the factor analysis, to create a simple and distinct matrix, the varimax rotation was applied, and the scree-plot was drawn to determine number of matrix components (the major dietary patterns). We selected the first three major dietary patterns with values greater than 1.5. Overall, each participant received a factor score for each dietary pattern based on the intake of weighed food groups by factor loading. To better display the associations, we trimmed three identified dietary patterns. 
Table 1

Food groupings used in the dietary pattern analyses

\begin{tabular}{|c|c|}
\hline Food groups & Dietary components \\
\hline $\begin{array}{l}\text { Leafy } \\
\text { vegetables }\end{array}$ & Cauliflower, lettuce, cucumber, onion, green bean, mushroom, pepper, garlic, turnip, others \\
\hline Fresh fruits & $\begin{array}{l}\text { Melon, watermelon, honeydew melon, plums, prunes, apples, cherries, sour cherries, peaches, nectarine, pear, fig, } \\
\text { date, grapes, kiwi, pomegranate, strawberry, banana, persimmon, berry, pineapple, oranges, others }\end{array}$ \\
\hline Dried fruits & Dried apricots, Dried berries, raisins, and other type dried fruits \\
\hline Dairy & Milk, yogurt, yogurt drink (doogh), cheese, chocolate milk, crud \\
\hline Tomato & Tomato \\
\hline $\begin{array}{l}\text { Carotene-rich } \\
\text { vegetables }\end{array}$ & Yellow squash, carrot \\
\hline Condiments & Condiments \\
\hline Pickles & Pickles \\
\hline Legumes & All type beans, peas,lentils, mung bean, soy \\
\hline Whole grain & Dark breads (Iranian), wheat, barley \\
\hline $\begin{array}{l}\text { Starchy } \\
\text { vegetables }\end{array}$ & Corn, eggplant, green peas, green squash \\
\hline Vegetable oil & Vegetable oil \\
\hline Natural juices & All fruit juices \\
\hline Butter & Butter, margarine, mayonnaise \\
\hline Olive & Olive and olive oil \\
\hline Organ meat & Heart, kidney, liver, tongue, brain, offal \\
\hline Read meat & Beef, lamb, minced meat \\
\hline Fish & All fish types \\
\hline $\begin{array}{l}\text { Processed } \\
\text { meat }\end{array}$ & Hamburger, sausage, delicatessen meat, pizza \\
\hline Soft drink & Soft drink \\
\hline Nuts & Almond, peanut, walnut, pistachio, hazelnut, seeds \\
\hline Egg & Egg \\
\hline Poultry & Chicken \\
\hline Snack & Corn puffs, potato chips, French fries \\
\hline $\begin{array}{l}\text { Sweets and } \\
\text { desserts }\end{array}$ & Cookies, cakes, biscuit, muffins, pies, chocolates, ice, honey, jam, sugar cubes, sugar, candies, others \\
\hline $\begin{array}{l}\text { Tea and } \\
\text { coffee }\end{array}$ & Tea and coffee \\
\hline $\begin{array}{l}\text { Hydrogenated } \\
\text { fat }\end{array}$ & Hydrogenated fats, animal fats \\
\hline Salt & Salt \\
\hline Potato & Potato \\
\hline Refined grain & White breads (lavash, baguettes), noodles, pasta, rice \\
\hline
\end{tabular}

Physical activity 
Physical activity level of the RaNCD participants was assessed using the standard questionnaire designed by PERSIAN Cohort. The questionnaire included 22 questions about the amount of daily activities of the person. Their responses were reported based on the metabolic equivalent of task per hour per day (MET/h/day). Detail of this questionnaire was described in previous study [14].

Outcome measurement

All participants completed self-reports about chronic LBP and the pain area was surveyed based on the RaNCD cohort study physician opinion and participants' response to her questions as follows: 1) Do you experience LBP that lasted more than a few months and interfered with their daily activities? In addition, has it lasted so far? (Yes/ No); 2) Do you have a history of back stiffness for more than an hour in the morning? (Yes/ No); 3) Do you have a history of arthralgia? (Yes/ No); 4) Do you have a history of joint stiffness for more than an hour in the morning? (Yes/ No). These questions were administered by the PERSIAN mega cohort study to evaluate chronic diseases in all Iranian adults ages $\geq 35$ years. Based on self-report and their medical history after physical examination by the physician, chronic LBP was diagnosed the presence of LBP for at a few months, which led to limit daily activities and had been sought for it's treatment, such as medication, medical consultation, or physiotherapy. Furthermore, the physician did not consider pain associated with malignancies, infections, and fractures as chronic LBP [17].

\section{Statistical analysis}

SPSS 20 (IBM Corp, Chicago, IL, USA) and Stata, version 14 (Stata Corp, College Station, TX) were applied for all statistical analysis. We reported quantitative variables by mean \pm standard deviation (SD), and qualitative variables using frequency (\%). Comparison of participants' baseline characteristics was evaluated using Chi-square and ANOVA test based on the tertiles of all three dietary patterns. Binary logistic regression in crude and adjusted odds ratios (OR) and $95 \%$ confidence intervals (Cl) was used to determine the association between chronic LBP and categories of three dietary patterns. In adjusted model 1, age (continuous), sex (categorical), smoking (categorical), and drinking (categorical) were adjusted. In adjusted model 2, we controlled the variables in model 1, diabetes (categorical), physical activity (continuous), body mass index (continuous), energy intake (continuous), and treatment for chronic LBP (categorical). In all analyses, the first tertile of dietary patterns was considered as the reference category. In addition, to better illustrate this association, we considered figure of linear regression OR across increased three major dietary patterns with adjustment for the mentioned variables in logistic regression. P-values were considered significant at the level of $<0.05$.

\section{Results}

In current study, 7686 of the RaNCD participants met the study inclusion criteria. $51.3 \%$ of them were male. We found that $22.5 \%$ of the participants had chronic LBP. The results of factor analysis introduced three dietary patterns with factor loading of food groups more than 0.2 (Table 2). The major dietary patterns were identified are as follows: 1) vegetarian dietary pattern which included vegetables, whole grain, legumes, nuts, olive, vegetable oil, fruits, and fruit juice; 2) high protein diet related to higher adherence to red and white

meat, legumes, nuts, and egg; and 3) unhealthy dietary pattern characterized with higher intake of salt, sweet, dessert, hydrogenated fat, soft drink, refined grain, tea, and coffee. Table 2 shows the rotated component matrix of each of the food groups and the correlation coefficient between each food group and dietary patterns. 
Table 2

Factor loading of food groups in all dietary patterns

\begin{tabular}{|c|c|c|c|}
\hline Food groups & Vegetarian dietary pattern & High protein dietary pattern & Unhealthy dietary pattern \\
\hline Leafy vegetables & .717 & - & - \\
\hline Fresh fruits & .630 & .274 & - \\
\hline Dried fruits & .563 & - & - \\
\hline Dairy & .485 & - & - \\
\hline Tomato & .455 & - & - \\
\hline Carotene-rich vegetables & .439 & .226 & - \\
\hline Condiments & .439 & - & - \\
\hline Pickles & .402 & - & - \\
\hline Legumes & .378 & .345 & - \\
\hline Whole grain & .369 & - & - \\
\hline Starchy vegetables & .354 & - & - \\
\hline Vegetable oil & .330 & - & -.248 \\
\hline Natural juices & .322 & .239 & - \\
\hline Butter & .319 & - & .276 \\
\hline Olive & .247 & - & - \\
\hline Organ meat & - & .611 & - \\
\hline Read meat & - & .578 & - \\
\hline Fish & - & .578 & - \\
\hline Processed meat & - & .516 & - \\
\hline Soft drink & - & .496 & .295 \\
\hline Nuts & .360 & .435 & - \\
\hline Egg & - & .330 & .221 \\
\hline Poultry & - & .311 & .209 \\
\hline Snack & - & .287 & .206 \\
\hline Sweets and desserts & - & - & .738 \\
\hline Tea and coffee & - & - & .654 \\
\hline Hydrogenated fat & - & - & .500 \\
\hline Salt & - & - & .388 \\
\hline Potato & .251 & - & .342 \\
\hline Refined grain & - & - & .331 \\
\hline Variance \% & 11.04 & 19.47 & 26.67 \\
\hline
\end{tabular}

The mean of BMI and WC in the highest tertiles of high protein and unhealthy diets were significantly lower than their lowest tertiles (P $<0.001)$, while higher adherence to vegetarian dietary pattern was significantly related to higher BMI and WC $(P<0.001)(T a b l e 3)$. 
Table 3

Baseline characteristics of studied participants

\begin{tabular}{|c|c|c|c|c|c|c|c|c|c|c|c|c|c|}
\hline \multirow[t]{3}{*}{ Variables } & \multirow{3}{*}{$\begin{array}{l}\text { Total } \\
(\mathrm{n}= \\
7686)\end{array}$} & \multicolumn{3}{|c|}{$\begin{array}{l}\text { Vegetarian dietary } \\
\text { pattern }\end{array}$} & \multirow[t]{3}{*}{$P * *$} & \multicolumn{3}{|c|}{$\begin{array}{l}\text { High protein dietary } \\
\text { pattern }\end{array}$} & \multirow[t]{3}{*}{$\mathrm{P} * \star$} & \multicolumn{3}{|c|}{ Unhealthy dietary pattern } & \multirow[t]{3}{*}{$\mathrm{P} * *$} \\
\hline & & $\mathrm{T} 1$ & T2 & T3 & & T1 & T2 & Т3 & & T1 & T2 & Т3 & \\
\hline & & $\begin{array}{l}(n= \\
2562)\end{array}$ & $\begin{array}{l}(n= \\
2562)\end{array}$ & $\begin{array}{l}(n= \\
2562)\end{array}$ & & $\begin{array}{l}(n= \\
2562)\end{array}$ & $\begin{array}{l}(n= \\
2562)\end{array}$ & $\begin{array}{l}(n= \\
2562)\end{array}$ & & $\begin{array}{l}(n= \\
2562)\end{array}$ & $\begin{array}{l}(n= \\
2562)\end{array}$ & $\begin{array}{l}(n= \\
2562)\end{array}$ & \\
\hline $\begin{array}{l}\text { Age } \\
\text { (year) }\end{array}$ & $\begin{array}{l}47.28 \\
\pm \\
7.99 *\end{array}$ & $\begin{array}{l}47.56 \\
\pm 8.19\end{array}$ & $\begin{array}{l}47.31 \\
\pm 8.04\end{array}$ & $\begin{array}{l}46.98 \\
\pm 7.74\end{array}$ & 0.032 & $\begin{array}{l}48.97 \\
\pm 8.11\end{array}$ & $\begin{array}{l}47.04 \\
\pm 7.92\end{array}$ & $\begin{array}{l}45.84 \\
\pm 7.63\end{array}$ & $<0.001$ & $\begin{array}{l}47.45 \\
\pm 8.13\end{array}$ & $\begin{array}{l}47.49 \\
\pm 7.98\end{array}$ & $\begin{array}{l}46.91 \\
\pm 7.86\end{array}$ & 0.015 \\
\hline $\begin{array}{l}\text { Weight } \\
(\mathrm{kg})\end{array}$ & $\begin{array}{l}72.77 \\
\pm \\
13.69\end{array}$ & $\begin{array}{l}70.24 \\
\pm \\
13.44\end{array}$ & $\begin{array}{l}72.86 \\
\pm 13.6\end{array}$ & $\begin{array}{l}75.23 \\
\pm \\
13.59\end{array}$ & $<0.001$ & $\begin{array}{l}70.75 \\
\pm \\
13.44\end{array}$ & $\begin{array}{l}72.16 \\
\pm \\
13.50\end{array}$ & $\begin{array}{l}75.41 \\
\pm \\
13.72\end{array}$ & $\begin{array}{l}< \\
0.001\end{array}$ & $\begin{array}{l}72.33 \\
\pm \\
12.97\end{array}$ & $\begin{array}{l}72.30 \\
\pm \\
13.47\end{array}$ & $\begin{array}{l}73.69 \\
\pm \\
14.55\end{array}$ & $\dot{0} 001$ \\
\hline $\begin{array}{l}\text { BMl } \\
\left(\mathrm{kg} / \mathrm{m}^{2}\right)\end{array}$ & $\begin{array}{l}27.28 \\
\pm 5.19\end{array}$ & $\begin{array}{l}26.48 \\
\pm 4.51\end{array}$ & $\begin{array}{l}27.33 \\
\pm 6.08\end{array}$ & $\begin{array}{l}28.03 \\
\pm 4.72\end{array}$ & $<.001$ & $\begin{array}{l}27.66 \\
\pm 4.83\end{array}$ & $\begin{array}{l}27.19 \\
\pm 6.10\end{array}$ & $\begin{array}{l}26.98 \\
\pm 4.47\end{array}$ & $\dot{0} 0.001$ & $\begin{array}{l}27.70 \\
\pm 6.01\end{array}$ & $\begin{array}{l}27.13 \\
\pm 4.47\end{array}$ & $\begin{array}{l}27 \pm \\
4.94\end{array}$ & $\begin{array}{l}< \\
0.001\end{array}$ \\
\hline WC (cm) & $\begin{array}{l}96.73 \\
\pm \\
10.67\end{array}$ & $\begin{array}{l}95.42 \\
\pm \\
11.01\end{array}$ & $\begin{array}{l}97.10 \\
\pm \\
10.37\end{array}$ & $\begin{array}{l}97.66 \\
\pm 10.5\end{array}$ & $<.001$ & $\begin{array}{l}97.45 \\
\pm \\
11.16\end{array}$ & $\begin{array}{l}96.46 \\
\pm \\
10.46\end{array}$ & $\begin{array}{l}96.27 \\
\pm \\
10.35\end{array}$ & $<.001$ & $\begin{array}{l}97.44 \\
\pm \\
10.30\end{array}$ & $\begin{array}{l}96.74 \\
\pm \\
10.21\end{array}$ & $\begin{array}{l}96 \pm \\
11.42\end{array}$ & $\dot{0.001}$ \\
\hline $\begin{array}{l}\text { PA (MET } \\
\text { hour/ } \\
\text { day( }\end{array}$ & $\begin{array}{l}41.27 \\
\pm 8.38\end{array}$ & $\begin{array}{l}41.46 \\
\pm 8.29\end{array}$ & $\begin{array}{l}41.27 \\
\pm 8.49\end{array}$ & $\begin{array}{l}41.06 \\
\pm 8.36\end{array}$ & 0.243 & $\begin{array}{l}40.83 \\
\pm 7.46\end{array}$ & $\begin{array}{l}40.99 \\
\pm 7.88\end{array}$ & $\begin{array}{l}41.98 \\
\pm 9.60\end{array}$ & $<0.001$ & $\begin{array}{l}39.36 \\
\pm 6.68\end{array}$ & $\begin{array}{l}41.21 \\
\pm 8.12\end{array}$ & $\begin{array}{l}43.23 \\
\pm 9.63\end{array}$ & ¿ 0.001 \\
\hline $\begin{array}{l}\text { Sex, } \\
\text { male, \% }\end{array}$ & 51.3 & 51.2 & 52.3 & 50.9 & 0.589 & 32.1 & 49.7 & 72.6 & $<.001$ & 41 & 49.7 & 63.7 & $<.001$ \\
\hline $\begin{array}{l}\text { Drinking, } \\
\%\end{array}$ & 6.6 & 6.7 & 6.9 & 6.3 & 0.689 & 2.3 & 5.7 & 12 & $<.001$ & 4.5 & 5.7 & 9.8 & $\hat{0.001}$ \\
\hline $\begin{array}{l}\text { Smoking, } \\
\%\end{array}$ & 20.4 & 22.7 & 20.6 & 18.2 & $\begin{array}{l}< \\
0.001\end{array}$ & 16.3 & 18.7 & 26.6 & $\begin{array}{l}< \\
0.001\end{array}$ & 11.5 & 19.3 & 30.6 & $\begin{array}{l}<.001 \\
0.00\end{array}$ \\
\hline $\begin{array}{l}\text { Diabetes, } \\
\%\end{array}$ & 6.5 & 4.8 & 6.6 & 8.2 & $\begin{array}{l}< \\
0.001\end{array}$ & 8.7 & 5.7 & 5.3 & $\hat{0}_{0.001}$ & 9.3 & 6.2 & 4.1 & $\begin{array}{l}<.001 \\
0.00\end{array}$ \\
\hline $\begin{array}{l}\text { Chronic } \\
\text { LBP, \% }\end{array}$ & 22.5 & 22.9 & 22.1 & 22.9 & 0.709 & 25.3 & 21.6 & 21.1 & $\begin{array}{l}< \\
0.001\end{array}$ & 21.8 & 22 & 24.1 & 0.101 \\
\hline
\end{tabular}

Our results showed that the mean of PA in all participants was $41.27 \pm 8.38$, in which in the third tertiles of high protein and unhealthy dietary pattern, the mean of PA was significantly higher than their first tertiles $(P<0.001)$ (Table 3$)$. According to this table, the prevalence of diabetes was $6.5 \%$ among these participants. In this study, the prevalence of chronic LBP decreased significantly with higher adherence to high protein dietary pattern $(P<0.001)$. However, this prevalence was not significantly different with higher following the two other major dietary patterns (vegetarian and unhealthy dietary pattern). Other characteristics of studied participants are presented in Table 3.

Multivariable-adjusted odds ratios and 95\% confidence intervals for chronic LBP across categories of three dietary patterns are indicated in Table 4. Compared with participants in the lowest tertile of high protein dietary pattern, those with higher adherence to this pattern were associated with lower risk of chronic LBP (OR: 0.79, 95\% Cl: 0.69-0.9); such that after controlling for age, sex, smoking, drinking, diabetes, physical activity, body mass index, energy intake and treatment this association remained (OR: $0.84,95 \% \mathrm{Cl}$ : 0.720.97). 
Table 4

Multivariable-adjusted odds ratios and 95\% confidence intervals for chronic low back pain across categories of three dietary patterns

\begin{tabular}{|c|c|c|c|c|}
\hline Major dietary pattern & Categories & Crude & Model 1* & Model 2* \\
\hline \multirow[t]{3}{*}{ Vegetarian dietary pattern } & T1 & 1 & 1 & 1 \\
\hline & $\mathrm{T} 2$ & $0.95(0.83-1.08)$ & $0.96(0.84-1.09)$ & $0.94(0.82-1.07)$ \\
\hline & T3 & $0.99(0.87-1.13)$ & $1.01(0.89-1.16)$ & $0.96(0.84-1.11)$ \\
\hline P-trend & & 0.965 & 0.798 & 0.633 \\
\hline \multirow[t]{3}{*}{ High protein dietary pattern } & $\mathrm{T} 1$ & 1 & 1 & 1 \\
\hline & $\mathrm{T} 2$ & $0.81(0.71-0.93)$ & $0.86(0.75-0.98)$ & $0.85(0.75-0.98)$ \\
\hline & T3 & $0.79(0.69-0.0 .9)$ & $0.88(0.76-1.01)$ & $0.84(0.72-0.97)$ \\
\hline P-trend & & $<0.001$ & 0.069 & 0.019 \\
\hline \multirow[t]{3}{*}{ Unhealthy dietary pattern } & $\mathrm{T} 1$ & 1 & 1 & 1 \\
\hline & $\mathrm{T} 2$ & $1(0.88-1.15)$ & $1.1(0.88-1.15)$ & $1(0.87-1.14)$ \\
\hline & T3 & $1.13(0.99-1.29)$ & $1.16(1.01-1.33)$ & $1.13(1.01-1.32)$ \\
\hline \multicolumn{2}{|l|}{ P-trend } & 0.055 & 0.026 & 0.05 \\
\hline
\end{tabular}

In addition, after controlling for the mentioned potential confounders, participants in the highest category of unhealthy dietary pattern were higher at risk of chronic LBP compared with those in the lowest category (OR: 1.13, 95\% Cl: 1.01-1.32). Figure 1 shows odds ratios and 95\% confidence intervals for chronic LBP across categories of high protein and unhealthy dietary pattern.

However, no significant association was found between adherence to vegetarian dietary pattern and chronic LBP either before or after adjusting the confounders (Table 4).

\section{Discussion}

According to our hypothesis, we found that higher adherence to high protein dietary pattern was associated with lower risk of chronic LBP; while risk of chronic LBP was increased with higher adherence to unhealthy dietary pattern. LBP is one of the pains that many people experience during adulthood and it is believed that nutrition can affect the formation and severity of chronic LBP [18, 19]. To the best our knowledge, the current study evaluated the relationship between major dietary pattern and risk of chronic LBP.

In current study, the prevalence of chronic LBP was significantly deccreased with higher adherance to high protein dietary pattern. There was a significant association between high protein dietary pattern and risk of chronic LBP. After controlling for potential confounders, participants who were in third tertile of high protein dietary pattern were $12 \%$ lower at risk of chronic LBP compared to participants in the lowest group. A randomized clinical trial by Kirk et al. [20] showed that dietary protein supplementation significantly improved skeletal muscle function. Another clinical trial by Shell et al.[21] showed that administration of amino acids precursors could improve chronic LBP and decrease level of IL-6 and CRP. Nutritional mechanisms in the development of chronic LBP include affecting brain-gut axis neurotransmitters and changes in gut derived neurotransmitters such as glutamate, which also affect the brain system and induce chronic pain [22]. Essential and semi-essential amino acids deficiency interfere with the production of neurotransmitter precursors that can affect pain sensation [21, 23]. Other factors worsening chronic LBP include decreased muscle mass and some degree of sarcopenia $[24,25]$. Skeletal muscle strength begins to decline in middle age in both men and women [26]. Adequate of protein intake is one of the main factors in maintaining this muscle strength [27]. The type and amount of protein determines the effect on muscle mass $[28,29]$. In this study, high protein diet related to higher adherence to red and white meat, legumes, nuts, and egg involving protein with high biological value and essential micronutrients (e.g., calcium, iron, zinc, choline, vitamin $\mathrm{B}_{12}$ ) that are important for growth and development, developing of neurotransmitters, improving of skeletal muscle mass and strength [30, 31]. 
Our study also found that adherence to unhealthy diet was positively associated with chronic LBP. After adjusting the potential confounders, participants who were in third tertile of unhealthy dietary pattern were $15 \%$ higher at risk of chronic LBP compared to participants in the lowest.

The components of unhealthy diet in our study is most similar to the Western diet involving higher intake of refined grains, red meat, processed meat, high saturated fat, trans-fatty acids, sweet sugary foods, and caffeine [11]. Following this dietary pattern was associated with increased level of inflammatory markers such as IL-6 and CRP, which can lead to a decrease in pain threshold in chronic LBP [32-34]. Song et al.[35] reported that in animal model high fat diet was related to increased chronic LBP. Another study was showed that higher adherance to sugary foods was decreased muscle strength (OR: $1.06 \mathrm{CI} 95 \%$ : 1.01-1.12) [36]. Other studies also found that low-protein, high-sugar, high-fat diets were associated with more chronic LBP and higher CRP levels [37-40]. Therefore, unhealthy diet in current study was characterized by intake of salt, sweet, dessert, hydrogenated fat, soft drink, refined grain, tea, and coffee in which these dietary components can increase inflammation and consequence chronic LBP.

In this study, no significant relationship was found between the vegetarian diet and chronic LBP. Although we controlled potential confounders, we did not observe any association between the vegetarian diet and chronic LBP. In fact, this dietary pattern contains high level of important antioxidants such as vitamin C, vitamin E, vitamin A, and all carotenoids [41, 42]. These antioxidants have antiinflammatory effects and can reduce the pain threshold in these patients [43]. On the other hand, vegetable-based diets produce shortchain fatty acids that stabilize the beneficial intestinal microbiome, and substances derived from this microbiome environment can affect the brain- gut system and reduce systemic and central inflammation [44]. Furthermore, this vegetable diet can relieve musculoskeletal pain [45]. In the present study, vegetarian dietary pattern was related to the intake of vegetables, whole grain, legumes, nuts, olive, vegetable oil, fruits, and fruit juice. The intake of these food groups in participants with and without chronic LBP seems to be the same and we could not find any association.

\section{Limitations}

This is the first study to evaluate the relationship between major dietary pattern and chronic LBP among Kurdish population; however, this study suffered from some limitations. Firstly, this is a cross- sectional study and the cause-and-effect relationship was not clear. Second, dietary intake was assessed by FFQ, and the error of recalling food intake should not be ignored. However, the questionnaire was presented by trained nutritionists. In addition, the degree and severity of chronic LBP in the RaNCD cohort study were not measured. Therefore, further studies are recommended without these limitations.

\section{Conclusions}

According to the findings of this study, higher adherence to high protein diet had protective effects on chronic LBP prevalence. In addition, we found that following unhealthy dietary pattern was associated with higher risk of chronic LBP. Therefore, it is recommended that people prone to chronic LBP consider a high biological value protein in their daily diet, and they reduce intake of salt, sweet, dessert, hydrogenated fat, soft drink, refined grain, tea, and coffee.

\section{Abbreviations}

Low back pain (LBP); C- reaction protein (CRP); tumor necrosis factor alpha (TNF-a); Ravansar non- communicable diseases (RaNCD); Body mass index (BMI); odds ratios (OR); confidence intervals (Cl)

\section{Declarations}

\section{Acknowledgments}

RaNCD is part of PERSIAN national cohort and we would like to thank Professor Reza Malekzadeh, Deputy of Research and Technology at the Ministry of Health and Medical Education of Iran and Director of the PERSIAN cohort, and also Dr. Hossein Poustchi Executive Director of PERSIAN cohort for all their supports during design and running of RaNCD.

Ethics approval and consent to participate: All procedures performed in studies involving human participants were in accordance with the ethical standards of the institutional and/or national research committee and with the 1964 Helsinki declaration and its later 
amendments or comparable ethical standards. This study was approved by the Ethics Committee of Kermanshah University of Medical Sciences (ethics approval number: KUMS.REC.1394.318).

Informed consent: Written informed consent was obtained from each studied subject after explaining the purpose of the study. The right of subjects to withdraw from the study at any time and subject's information is reserved and will not be published.

Consent for publication: Not applicable

Availability of data and materials: Data will be available upon request from the corresponding author.

Competing interests: All authors have no conflict of interest.

Funding: This study was supported by Ministry of Health and Medical Education of Iran and Kermanshah University of Medical Science (Grant No: 92472).

Authors' contributions: SM and YP equally contributed to the conception and design of the research; FN, $\mathrm{BH}$, and YP contributed to data collection; SM, YP and MM contributed to the acquisition and analysis of the data; SM, SK and AM contributed to the interpretation of the data; and SM, SK, AM and YP contributed to draft the manuscript. All authors are in agreement with the manuscript and declare that the content has not been published elsewhere.

\section{References}

1. Urits I, Burshtein A, Sharma M, Testa L, Gold PA, Orhurhu V, et al. Low back pain, a comprehensive review: pathophysiology, diagnosis, and treatment. Curr Pain Headache Rep. 2019;23(3):23.

2. Torlak MS, Bagcaci S, Akpinar E, Okutan O, Nazli MS, Kuccukturk S. The effect of intermittent diet and/or physical therapy in patients with chronic low back pain: A single-blinded randomized controlled trial. EXPLORE. 2020.

3. Shamsi M, Sarrafzadeh J, Jamshidi A, Arjmand N, Ghezelbash F. Comparison of spinal stability following motor control and general exercises in nonspecific chronic low back pain patients. Clin Biomech. 2017;48:42-8.

4. Bratton RL. Assessment and management of acute low back pain. Am Fam Physician. 1999;60(8):2299.

5. Bento TPF, dos Santos Genebra CV, Maciel NM, Cornelio GP, Simeão SFAP, de Vitta A. Low back pain and some associated factors: is there any difference between genders? Braz J Phys Ther. 2020;24(1):79-87.

6. Shamsi M, Safari A, Samadzadeh S, Yoosefpour N. The prevalence of musculoskeletal pain among above 50-year-old population referred to the Kermanshah-Iran health bus in 2016. BMC Research Note. 2020;13(1):72.

7. Zick SM, Murphy SL, Colacino J. Association of chronic spinal pain with diet quality. Pain Report. 2020;5(5).

8. Philpot U, Johnson MI. Diet therapy in the management of chronic pain: better diet less pain? Future Medicine; 2019.

9. Teodorczyk-Injeyan JA, Triano JJ, Injeyan HS. Nonspecific Low Back Pain: Inflammatory Profiles of Patients With Acute and Chronic Pain. Clin J Pain. 2019;35(10):818.

10. Barbaresko J, Rienks J, Oluwagbemigun K, Jacobs G, Lieb W, Laudes M, et al. Dietary patterns associated with inflammatory biomarkers in a Northern German population. Eur J Nutr. 2020;59(4):1433-41.

11. Samadi M, Moradi S, Moradinazar M, Mostafai R, Pasdar Y. Dietary pattern in relation to the risk of Alzheimer's disease: a systematic review. Neurol Sci. 2019:1-13.

12. Calle MC, Andersen CJ. Assessment of dietary patterns represents a potential, yet variable, measure of inflammatory status: a review and update. Dis Marker. 2019;2019.

13. Pasdar Y, Moradi S, Moludi J, Darbandi M, Niazi P, Nachvak SM, et al. Risk of metabolic syndrome in non-alcoholic fatty liver disease patients. Med J Nutrition Metab. 2019;12(4):353-63.

14. Pasdar Y, Najafi F, Moradinazar M, Shakiba E, Karim H, Hamzeh B, et al. Cohort profile: Ravansar Non-Communicable Disease cohort study: the first cohort study in a Kurdish population. Inter J Epidemiol. 2019;48(3):682-3f.

15. Poustchi H, Eghtesad S, Kamangar F, Etemadi A, Keshtkar A-A, Hekmatdoost A, et al. Prospective epidemiological research studies in Iran (the PERSIAN Cohort Study): rationale, objectives, and design. Am J Epidemiol. 2018;187(4):647-55.

16. Moradi S, Pasdar Y, Hamzeh B, Najafi F, Nachvak SM, Mostafai R, et al. Comparison of 3 nutritional questionnaires to determine energy intake accuracy in Iranian adults. Clin Nutr Res. 2018;7(3):213-22.

Page $10 / 12$ 
17. Pasdar Y, Hamzeh B, Moradi S, Cheshmeh S, Najafi F, Moradinazar M, et al. Better muscle strength can decrease the risk of arthralgia and back \&joint stiffness in Kurdish men; a cross-sectional study using data from RaNCD cohort study. BMC Musculoskeletal Disord. 2020.

18. Manchikanti L, Singh V, Datta S, Cohen SP, Hirsch JA. Comprehensive review of epidemiology, scope, and impact of spinal pain. Pain Physician. 2009;12(4):E35-70.

19. Lim SS, Vos T, Flaxman AD, Danaei G, Shibuya K, Adair-Rohani H, et al. A comparative risk assessment of burden of disease and injury attributable to 67 risk factors and risk factor clusters in 21 regions, 1990-2010: a systematic analysis for the Global Burden of Disease Study 2010. Lancet (London, England). 2012;380(9859):2224-60.

20. Kirk B, Mooney K, Amirabdollahian F, Khaiyat O. Exercise and dietary-protein as a countermeasure to skeletal muscle weakness: Liverpool Hope University-Sarcopenia Aging Trial (LHU-SAT). Front Physiol. 2019;10:445.

21. Shell WE, Pavlik S, Roth B, Silver M, Breitstein ML, May L, et al. Reduction in Pain and Inflammation Associated With Chronic Low Back Pain With the Use of the Medical Food Theramine. Am J Ther. 2016;23(6):e1353-e62.

22. Kawase T, Nagasawa M, Ikeda H, Yasuo S, Koga Y, Furuse M. Gut microbiota of mice putatively modifies amino acid metabolism in the host brain. Br J Nutr. 2017;117(6):775-83.

23. Shell WE, Pavlik S, Roth B, Silver M, Breitstein ML, May L, et al. Reduction in Pain and Inflammation Associated With Chronic Low Back Pain With the Use of the Medical Food Theramine. Am J Ther. 2016;23(6):e1353-e62.

24. Sakai Y, Matsui H, Ito S, Hida T, Ito K, Koshimizu H, et al. Sarcopenia in elderly patients with chronic low back pain. Osteoporos Sarcopenia. 2017;3(4):195-200.

25. Kim WJ, Kim KJ, Song DG, Lee JS, Park KY, Lee JW, et al. Sarcopenia and Back Muscle Degeneration as Risk Factors for Back Pain: A Comparative Study. Asian spine journal. 2020;14(3):364-72.

26. Kuo Y-K, Lin Y-C, Lee C-Y, Chen C-Y, Tani J, Huang T-J, et al. Novel Insights into the Pathogenesis of Spinal Sarcopenia and Related Therapeutic Approaches: A Narrative Review. Int J Mol Sci. 2020;21(8):3010.

27. Chen TJ, Blum K, Payte JT, Schoolfield J, Hopper D, Stanford M, et al. Narcotic antagonists in drug dependence: pilot study showing enhancement of compliance with SYN-10, amino-acid precursors and enkephalinase inhibition therapy. Med Hypotheses. 2004;63(3):538-48.

28. Børsheim E, Tipton KD, Wolf SE, Wolfe RR. Essential amino acids and muscle protein recovery from resistance exercise. Am J Physiol Endocrinol Metab. 2002;283(4):E648-E57.

29. Samadi M, Moradi S, Azadbakht L, Rezaei M, Hojati N. Adherence to healthy diet is related to better linear growth with open growth plate in adolescent girls. Nutr Res. 2020;76:29-36.

30. Headey D, Hirvonen K, Hoddinott J. Animal sourced foods and child stunting. Am J Agric Econ. 2018;100(5):1302-19.

31. Pasdar Y, Moradi S, Esfahani NH, Darbandi M, Niazi P. Intake of Animal Source Foods in Relation to Risk of Metabolic Syndrome. Prev Nutr Food Sci. 2020;25(2):133.

32. Sullivan PM. Influence of Western diet and APOE genotype on Alzheimer's disease risk. Neurobiol Dis. 2020;138:104790.

33. Barbaresko J, Koch M, Schulze MB, Nöthlings U. Dietary pattern analysis and biomarkers of low-grade inflammation: a systematic literature review. Nutrition reviews. 2013;71(8):511-27.

34. Briggs MS, Givens DL, Schmitt LC, Taylor CA. Relations of C-reactive protein and obesity to the prevalence and the odds of reporting low back pain. Arch Phys Med Rehabil. 2013;94(4):745-52.

35. Song Z, Xie W, Chen S, Strong JA, Print MS, Wang JI, et al. High-fat diet increases pain behaviors in rats with or without obesity. Scientific Report. 2017;7(1):1-14.

36. Pasdar Y, Moradi S, Moradinazar M, Hamzeh B, Najafi F. Better muscle strength with healthy eating. Eat Weight Disord. $2020: 1-8$.

37. Lim YZ, Wang Y, Cicuttini FM, Hughes HJ, Chou L, Urquhart DM, et al. Association Between Inflammatory Biomarkers and Nonspecific Low Back Pain: A Systematic Review. Clin J Pain. 2020;36(5):379-89.

38. Bärebring L, Winkvist A, Gjertsson I, Lindqvist HM. Poor Dietary Quality Is Associated with Increased Inflammation in Swedish Patients with Rheumatoid Arthritis. Nutrients. 2018;10(10).

39. Zick SM, Murphy SL, Colacino J. Association of chronic spinal pain with diet quality. Pain Report. 2020;5(5):e837-e.

40. Elma Ö, Yilmaz ST, Deliens T, Coppieters I, Clarys P, Nijs J, et al. Do Nutritional Factors Interact with Chronic Musculoskeletal Pain? A Systematic Review. J Clin Med. 2020;9(3):702. 
41. Steck S, Shivappa N, Tabung F, Harmon B, Wirth M, Hurley T, et al. The dietary inflammatory index: a new tool for assessing diet quality based on inflammatory potential. Digest. 2014;49(3):1-10.

42. Pasdar Y, Hamzeh B, Moludi J, Mehaki B, Darbandi M, Moradi S. Dietary intake and risk of depression among male and female with HIV/AIDS. Eat Weight Disord. 2019:1-10.

43. Volpi E, Kobayashi H, Sheffield-Moore M, Mittendorfer B, Wolfe RR. Essential amino acids are primarily responsible for the amino acid stimulation of muscle protein anabolism in healthy elderly adults. Am J Clin Nutr. 2003;78(2):250-8.

44. Pimentel GD, Micheletti TO, Pace F, Rosa JC, Santos RV, Lira FS. Gut-central nervous system axis is a target for nutritional therapies. Nutrition journal. 2012;11:22.

45. Towery P, Guffey JS, Doerflein C, Stroup K, Saucedo S, Taylor J. Chronic musculoskeletal pain and function improve with a plantbased diet. Complement Ther Med. 2018;40:64-9.

\section{Figures}

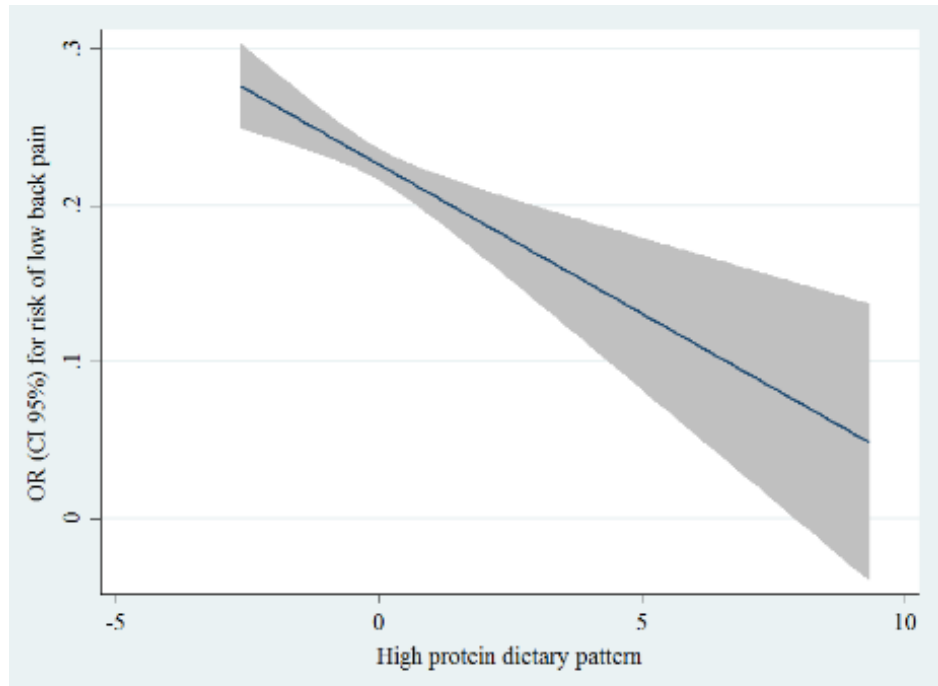

a

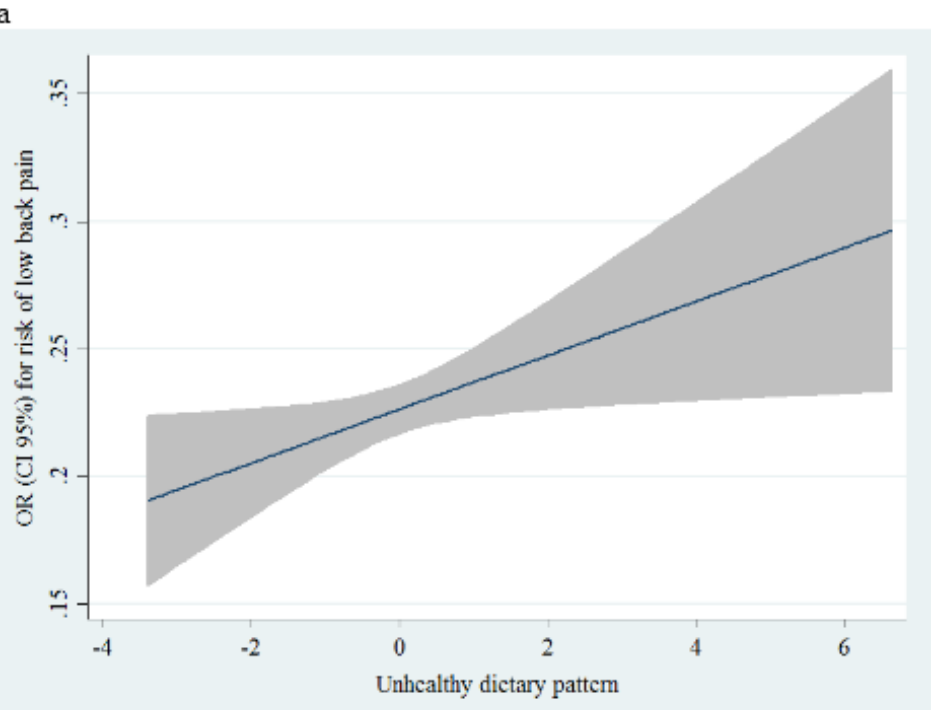

b

\section{Figure 1}

Liner regression odds ratios and $95 \%$ confidence intervals for chronic low back pain across categories of high protein (a) and unhealthy dietary pattern (b) 